\title{
Mineralogy of Drill Hole UE-25p\#1 \\ at Yucca Mountain, Nevada
}

Steve J. Chipera

David L. Bish

\section{DISCLAIMER}

Whas prepared as an account of work sponsored by an agency of the Uniled and their This report was prepared as United States Government nor any agency liegal liability or responsiGovernment. Neither the United Stapress or inplied, or assu information, apparatus, product, or employees, makes any wartanty. express, or usefulness of any informe privately owned rights. Referbility for the accuracy, completeness, or use would not iniringe prive by trade name, traderecomprocess disclosed, or represents that ial produci, process, or servitute or imply its endorsent. The views ence herein to any specifyise does not necessarily constiment or any agency theref. The of the manufacturer, or otherwise doe United States Govern mendation, or favoring by the Unesed herein do not

and opinions of authors expressed herein thereof.
United States Government or any agency ther 
MTNERALOGY OF DRILL HOLE UE-25P\#1 AT YUCCA MOUNTAIN, NEVADA

by

Steve J. Chipera and David L. Bish

\section{ABSTRACT}

Drill hole UE-25p\#1 is located east of the candidate repository block at Yucca Mountain, Nevada, and as such provides information on the geology of the accessible environment. The hole was drilled to a depth of $1807 \mathrm{~m}(5823 \mathrm{ft})$ and is unique in that it penetrates tuffs that are older than any volcanic units previously encountered in drill holes at Yucca Mountain. In addition, it is the only hole drilled to date that penetrates the base of the tuff sequence and enters the underlying Paleozoic dolomite basement. We have examined the mineralogy of drill cuttings, core, and sidewall samples from drill hole UE-25p\#1 using quantitative $x-$ ray powder diffraction methods. The mineral distribution in the volcanic rocks in UE-25p\#1 is similar to that in the other drill holes examined at Yucca Hountain. The only significant differences in mineralogy from other drill holes include the presence of dolomite in the Paleozoic carbonate rocks and the occurrence of up to $3 \%$ laumontite, a Ca-zeolite, in four samples of the Lithic Ridge Tuff. Tridymite occurs only near the surface, coexisting with cristobalite before disappearing. Cristobalite disappears with the first appearance of zeolites, and opal-CT is a prominent phase coexisting with clinoptilolite. Analcime increases in abundance with depth, perhaps forming from clinoptilolite, but it coexists with clinoptilolite (or heulandite) to its deepest occurrence. One coexisting analcime-clinoptilolite sample was examined to determine the exact nature of the zeolites; the clinoptilolite-heulandite group mineral in this sample was heulandite, in contrast to many of the shallower clinoptilolites at Yucca Mountain. Mordenite, a common zeolite in other drill holes at Yucca Mountain, was identified in only 4 of 40 zeolitebearing samples in UE-25p\#1. Minor amounts of kaolinite and chlorite occur in limited intervals. However, interstratified illite/smectites (I/S) were the most abundant clay minerals, and most samples examined contained two distinct I/S. At and below the 1072.8-m (3520-ft) depth, the two I/S consisted of randomly interstratified I/S with less than 20\% collapsed layers and $\mathrm{R}=1$-ordered $\mathrm{I} / \mathrm{S}$ with $60 \%$ to $75 \%$ collapsed layers. This I/S assemblage is similar to that which occurs in drill holes USW G-1 and G-2, and it is likely that the $R=1 \mathrm{I} / \mathrm{S}$ in UE-25p\#1 correlate with the ordered interstratifications in G-1 and G-2, which have $\mathrm{K} / \mathrm{Ar}$ dates of approximately $11 \mathrm{Myr}$ and are linked to Timber Mountain volcanism. The higher temperature $\mathrm{I} / \mathrm{S}$ in this hole suggest a maximum alteration temperature of $175^{\circ} \mathrm{C}$. 


\section{INTRODUCTION}

The mineralogy and petrology of the rocks at Yucca Mountain, Nevada, are being investigated to determine Yucca Mountain's suitability to host a geologic high-level radioactive waste repository. This research, sponsored by the Nevada Nuclear Waste Storage Investigations (NNWSI) Project and directed by the Haste Management Project Office of the U.S. Department of Energy, Nevada Operations office, is concerned with defining the lateral and horizontal variability of the volcanic tuffs that make up Yucca Mountain and the surrounding areas. If Yucca Mountain is selected as a nuclear waste repository, the geologic materials that compose the site must be the ultimate container capable of isolating radioactive wastes from the accessible environment. UE-25p\#1, located to the east of the repository block, is one of numerous drill holes emplaced in and around Yucca Mountain (Fig. 1) to provide samples for determining the mineralogic and petrologic variability of the tuffs that underlie the site.

A stratigraphic column for UE-25p\#1 is shown in Table I. In addition to the volcanic sequence typically found in other drill holes, UE-25p\#1 penetrates tuffs that are older than any volcanic units previously encountered in drill holes at Yucca Mountain. The deepest of these tuff units is believed to be equivalent to the Tuff of Yucca Flat (Carr et al. 1986). UE-25p\#1 is also the only hole drilled to date that penetrates the volcanic tuff sequences and enters the underlying Paleozoic dolomite basement.

\section{EXPERIMENTAL TECHNIQUES}

The volcanic rocks at Yucca Mountain commonly have a very fine grained groundmass that is not amenable to quantitative mineral analysis by optical petrographic techniques. Therefore, the data in this report were obtained solely by $x$-ray powder diffractometer techniques.

The data presented here were obtained primarily from drill-cutting samples, although four sidewall samples and four drill-core samples (Table II) were also analyzed. Typically 15 to $20 \mathrm{~g}$ of sample was crushed in a shatterbox to provide a homogeneous powder. A small portion of each sample ( 1 to $3 \mathrm{~g}$ ) was then ground under acetone in an automatic Brinkmann Retsch mill (fitted with an agate mortar and pestle) for longer than 10 min to produce an average particle size of less than $5 \mu \mathrm{m}$. To confirm the adequacy of our grinding times and techniques, the particle size distributions of several samples were measured 


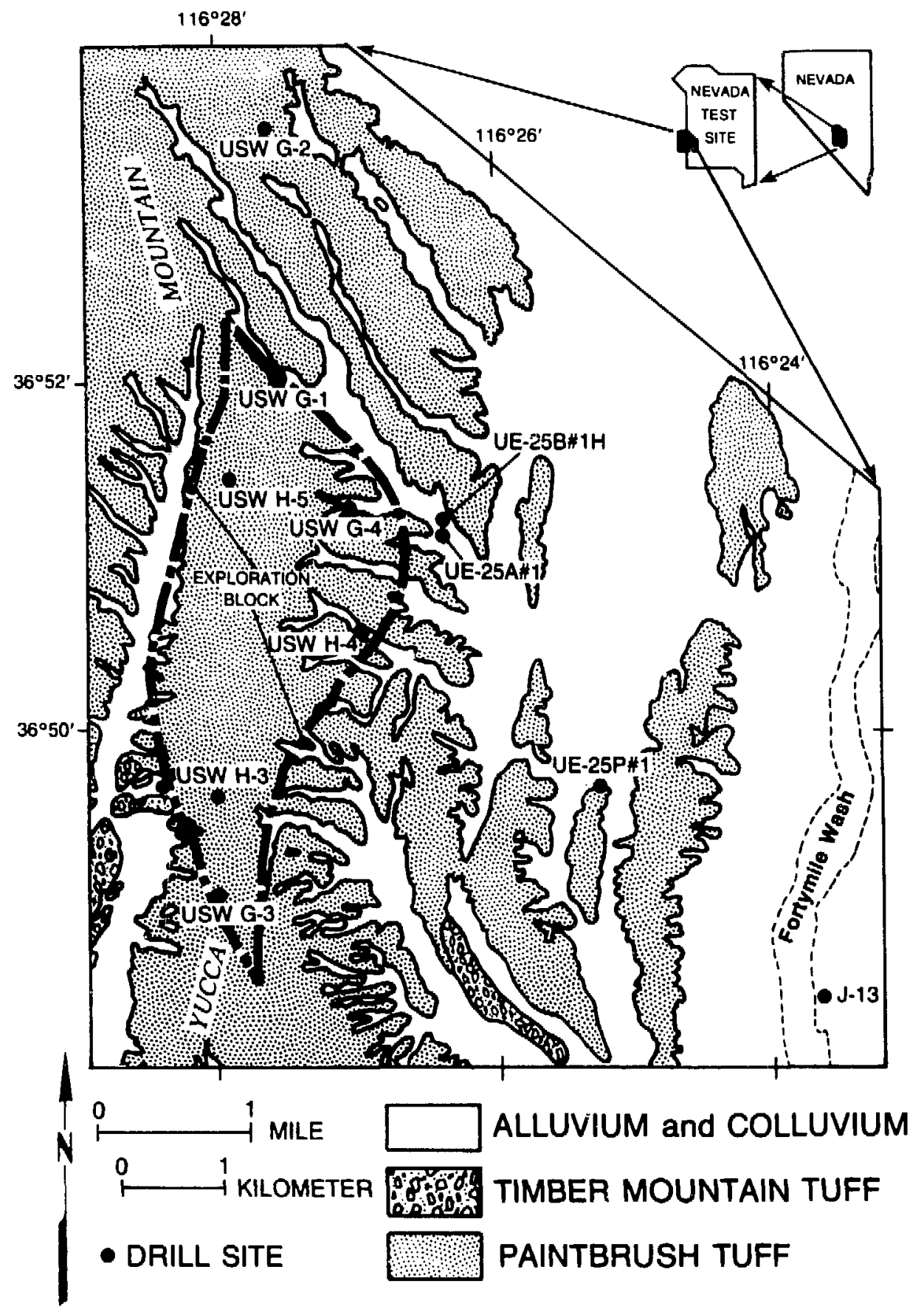

Fig. 1. Location map of Yucca Mountain, Nevada, showing the outline of the exploration block for the NNWSI Project and the locations of drill holes mentioned in the text. 


\section{TABLB I}

YAJOR STRATIGRAPHIC UNITS AND CONTACTS IN DRILL HOLB UB-25p\$1 (from Carr et al. 1986)

\begin{tabular}{|c|c|c|c|}
\hline Unit & \multirow{2}{*}{$\frac{\begin{array}{c}\text { Depth of Interval } \\
\text { m (ft) }\end{array}}{0-39(0-128)}$} & \multicolumn{2}{|c|}{$\begin{array}{c}\text { Thickness } \\
\text { of Interval } \\
\text { m (Pt) } \\
\end{array}$} \\
\hline Alluvium & & 39 & $(128)$ \\
\hline \multicolumn{4}{|c|}{-.- unconformity _-.-- } \\
\hline $\begin{array}{l}\text { Timber Mountain Tuff } \\
\text { Rainier Yesa Member }\end{array}$ & $38-52(128-170)$ & 13 & $(42)$ \\
\hline $\begin{array}{l}\text { Paintbrush Tuff } \\
\text { Bedded tuff } \\
\text { Tiva Canyon Member }\end{array}$ & $\begin{array}{l}\text { ormity } \\
52-55(170-180) \\
55-78(180-255)\end{array}$ & $\begin{array}{r}3 \\
23\end{array}$ & $\begin{array}{l}(10) \\
(75)\end{array}$ \\
\hline \multicolumn{4}{|c|}{$---\cdots--$ fault $--\cdots-\cdots$} \\
\hline Topopah Spring Kember & $81-381 \quad(267-1250)$ & 300 & $(983)$ \\
\hline Rhyolite of Calico Hills & $381-436(1250-1430)$ & 55 & $(180)$ \\
\hline $\begin{array}{l}\text { Crater Flat Tuff } \\
\text { Prow Pass Member } \\
\text { Bedded tuff } \\
\text { Bullfrog Member } \\
\text { Bedded tuff } \\
\text { Tram Member }\end{array}$ & $\begin{array}{ll}436-547 & (1430-1792) \\
547-558 & (1792-1830) \\
558-683 & (1830-2240) \\
683-691 & (2240-2265) \\
691-873 & (2265-2863)\end{array}$ & $\begin{array}{r}111 \\
11 \\
125 \\
8 \\
182\end{array}$ & $\begin{array}{r}(362) \\
(38) \\
(410) \\
(25) \\
(598)\end{array}$ \\
\hline \multicolumn{4}{|c|}{$-\cdots-\cdots-$ fault $-\cdots-\cdots$} \\
\hline Lithic Ridge Tuff & 873-1064（2863-3488) & 191 & $(625)$ \\
\hline Bedded tuff & $1064-1068(3488-3502)$ & 4 & $(14)$ \\
\hline $\begin{array}{l}\text { Older tuffs of drill hole } \\
\text { Unit A } \\
\text { Unit C }\end{array}$ & $\begin{array}{ll}1068-1101 & (3502-3610) \\
1101-.1139 & (3610-3733)\end{array}$ & $\begin{array}{l}33 \\
38\end{array}$ & $\begin{array}{l}(108) \\
(123)\end{array}$ \\
\hline Sedimentary deposits & $1138-1172(3733-3844)$ & 33 & (111) \\
\hline $\begin{array}{l}\text { Calcified tuff } \\
\text { Tuff of Yucca Flat(?) }\end{array}$ & $\begin{array}{l}1172-1205(3844-3950) \\
1205-1244(3850-4080)\end{array}$ & $\begin{array}{l}33 \\
39\end{array}$ & $\begin{array}{l}(106) \\
(130)\end{array}$ \\
\hline \multicolumn{4}{|c|}{------- fault -------} \\
\hline $\begin{array}{l}\text { Lone Yountain Dolomite } \\
\text { Roberts Mountain Formation }\end{array}$ & $\begin{array}{l}1244-1668(4080-5470) \\
1668-1807 \quad(5470-5923)\end{array}$ & $\begin{array}{l}424 \\
139\end{array}$ & $\begin{array}{r}(1390) \\
(453)\end{array}$ \\
\hline
\end{tabular}


using a Horiba CAPA-500 automatic particle size distribution analyzer. A halfgram portion of most samples was mixed with a $1.0-\mu$ m corundum $\left(\mathrm{Al}_{2} \mathrm{O}_{3}\right)$ internal standard in the ratio of $80 \%$ sample to $20 \%$ corundum; the only exceptions were seven samples for which insufficient sample existed to retain both a pure sample and a sample mixed with an internal standard. These seven samples were analyzed without an internal standard, using the "adiabatic" method of Chung $(1974 b)$.

For consistency, the drill-cutting samples were all labeled following the convention adopted by F. M. Byers (personal communication, November 1985). The drill cuttings represent material washed out of drill holes over 10-ft intervals. The footage at the bottom of each 10-ft interval was used to designate the sample number. For example, sample UE-25p\#1-3040 represents cuttings taken from drill hole UE-25p\#l from an interval between 923.5 and $926.6 \mathrm{~m}$ (3030 to $3040 \mathrm{ft}$ ) in depth. Exceptions are that sample UE-25p\#1-1598 is from the interval 484.6 to $487.1 \mathrm{~m}$ (1590 to $1598 \mathrm{ft}$ ) and sample UE-25p\#1-4318 is from the interval 1314.6 to $1316.1 \mathrm{~m}$ (4313 to $4318 \mathrm{ft}$ ). All samples in this report are drill cuttings unless designated with an "SW" for sidewall samples or "C" for drill-core samples.

All diffraction patterns were obtained on an automated Siemens D-500 diffractometer using copper-Ka radiation, a diffracted-beam monochrometor, and pulse-height analysis. Data were collected automatically in the step-scan mode with a step size of $0.02^{\circ} 2 \theta$ and count times of at least 2.0 s per step. Data were commonly collected from $2.0^{\circ}$ to $50.0^{\circ} 2 \theta$ for both pure samples and samples mixed with a $1.0-\mu \mathrm{m}$ corundum internal standard. Mineral identification was accomplished by comparing observed patterns with patterns of pure standards, published patterns from the Joint Committee on Powder Diffraction Standards, or calculated mineral patterns.

\section{QUUANTITATIVE ANALYSIS}

Most quantitative analyses for this report employed the internal standard or "matrix-flushing" method of Chung (1974a) using synthetic 1.0- $\mu$ m corundum as the internal standard. The seven samples that were too small to be mixed with corundum were analyzed by the external standard or "adiabatic" method of chung (1974b). Both of these methods require that reference intensity ratios (RIRs) be determined before sample analysis. 


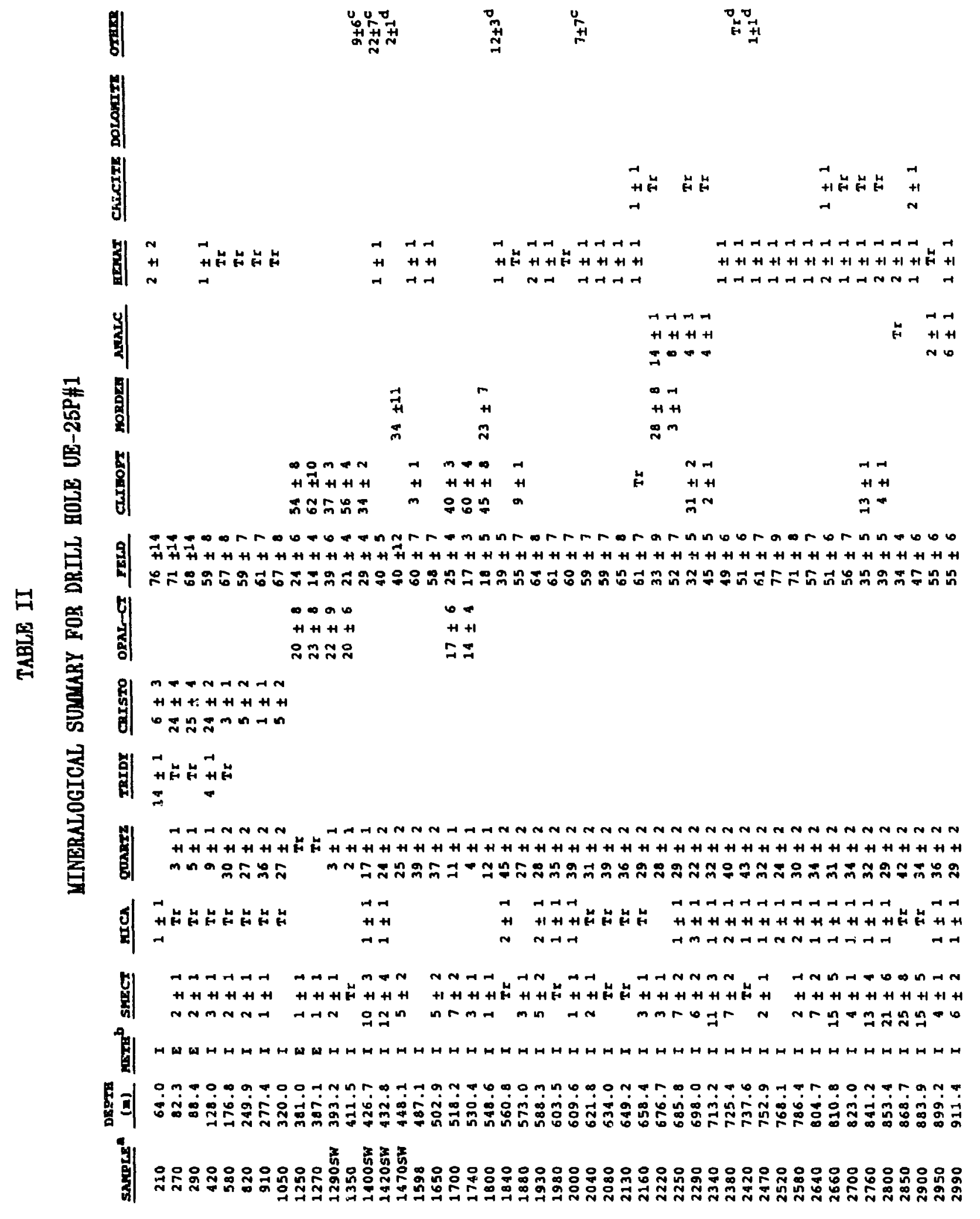


DEPTH

SAMPLE

$3040 \quad 926.6 \quad I 11 \pm 3$

$3090 \quad 941.911 \pm 3$

$\begin{array}{rrrr}3090 & 941.8 & \text { I } & 15 \pm 2 \\ 3140 & 957.1 & \text { I } & 6 \pm 2\end{array}$

$\begin{array}{rrrr}3140 & 957.1 & \text { I } & 6 \pm 2 \\ 3170 & 966.2 & \text { I } & 13 \pm 4\end{array}$

$3240 \quad 987.6 \quad I \quad 5 \pm 2$

$3280 \quad 999.7$ I $5 \pm 2$

$3330 \quad 1015.0$ E $25 \pm 10$

$\begin{array}{llll}3380 & 1030.2 & 1 & 22 \pm 7\end{array}$

$3420 \quad 1042.4$ I $7 \pm 2$

$3453 \mathrm{C} 1052.5$ I $6 \pm 2$

$\begin{array}{rrrr}3490 & 1063.8 & \text { I } & 7 \pm 2 \\ 3520 & 1072.9 & \text { I } & 11 \pm 3\end{array}$

$3560 \quad 1085.1$

35601085.1

1097.3

$3660 \quad 1115.6$ I $19 \pm 6$

$3670 \quad 1118.6 \quad I \quad 16 \pm 5$

$3700 \quad 1127.9$ I $15 \pm 5$

$3730 \quad 1136.9$ E $20 \pm 8$

$3760 \quad 1146.0$ I $15 \pm 5$

38001158.2 I $14 \pm 4$

$3830 \quad 1167.4$ I $9 \pm 3$

$3870 \quad 1179.6$ I $10 \pm 3$

$3913 \mathrm{C} \quad 1192.7$ I $37 \pm 11$

$3916 \mathrm{C} 1193.6$ I $45 \pm 14$

$3928 \mathrm{C} \quad 1197.3$ I $40 \pm 12$

$3950 \quad 1204.0$ I $9 \pm 3$

$\begin{array}{llll}3990 & 1216.2 & \text { I } & 13 \pm 4 \\ 4050 & 1234.4 & \text { I } & 16 \pm 5\end{array}$

$4080 \quad 1243.6$ I $29 \pm 9$

$4090 \quad 1249.1 \quad I \quad 2 \pm$

$\begin{array}{llll}4180 & 1274.1 & I & 9 \pm 3 \\ 4318 & 1316.1 & I & 1 \pm 1\end{array}$
Mxch QunRTz

Tr $30 \pm 2$

Tr $44 \pm 2$

Tr $34 \pm 2$

$\operatorname{Tr} 37 \pm 2$

$38 \pm 2$

$36 \pm 2$

$38 \pm 5$

$35 \pm 2$

$35 \pm 2$

$38 \pm 2$

$40 \pm 2$

$40 \pm 2$
$37 \pm 2$

$2 \pm 143 \pm 2$

$1 \pm 142 \pm 5$

$42 \pm 2$

$32 \pm 2$

$29 \pm 2$

$1 \pm 130 \pm 2$

$36 \pm 2$

$27 \pm 4$

$33 \pm 2$

$35 \pm 2$

$44 \pm 2$

$52 \pm 3$

$53 \pm 3$

$49 \pm 2$

$18 \pm 1$

$39 \pm 2$

$32 \pm 3$

12

$1 \pm 130 \pm 2$

$5 \pm 1$

$8 \pm 1$

$4 \pm 1$

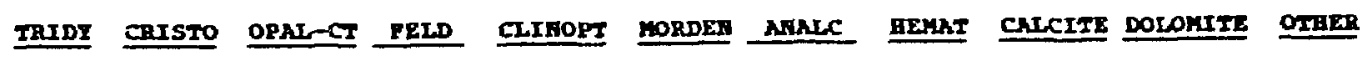
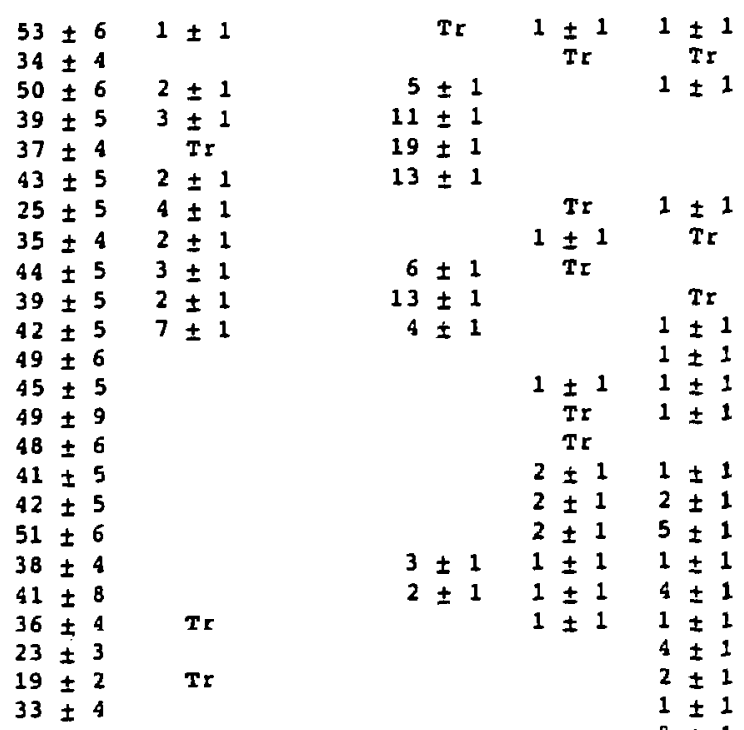

$5 \pm 1$

$11 \pm 1$

$19 \pm 1$

$13 \pm 1$

$\begin{array}{ccc} & \operatorname{Tr} & 1 \pm 1 \\ 6 \pm 1 & 1 \pm 1 & \operatorname{Tr}\end{array}$

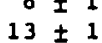

$13 \pm 1$
$4 \pm 1$

Tr

$\begin{array}{cl}1 \pm 1 & 1 \pm 1 \\ \operatorname{Tr} & 1 \pm 1\end{array}$

$\begin{array}{lll}\operatorname{Tr} & & \\ 2 \pm 1 & 1 \pm 1 \\ 2 \pm 1 & 2 \pm 1\end{array}$

$2 \pm 1 \quad 2 \pm 1$

$3 \pm 1 \quad 1 \pm 1 \quad 1 \pm 1$

$2 \pm 1 \quad 1 \pm 1 \quad 4 \pm 1$

$1 \pm 1$

$1 \pm 1 \quad 8 \pm 1$

$\begin{array}{lll}4 \pm 1 & 21 \pm 2 \\ 2 \pm 1 & 22 \pm 2\end{array}$

$2 \pm 1$
$1 \pm 1$

$8 \pm 1$
$3 \pm 1$

$47 \pm 2$

$44 \pm 5$

$29 \pm 3 \quad 2 \pm 1$

$29 \pm 3$
$38 \pm 5$

$1 \pm 1 \quad 23 \pm 2$

$\begin{array}{lr}1 & 23 \pm 1 \\ T I & 8 \pm 1\end{array}$

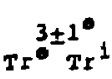

$\operatorname{Tr}^{f}$

$7 \pm 3$
$4 \pm 1$

$T r \underbrace{4 \pm 1}_{1 \pm 1} f$

$3 \pm 1$

$1 \pm 1^{9}$

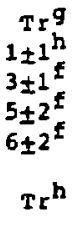

$3 \pm 1$ 85 \pm 6

$4 \pm 1 \quad 80 \pm 6$

$6 \pm 2 \quad 1 \pm 19$

$4 \pm 1 \quad 1 \pm 19$

$1 \pm 19 \quad \mathrm{Tr}^{2}$

$3 \pm 1$ 1 19

$x x^{\circ} 41$

- Samples followed by SW are sidewall samples; those followed by C ero drill core semples. The remaining samples are all drill cuttings. b = Run uaing the Internal Standerd Method; $E$ = Run using the External Stundard Mothod.

\section{I = Run}

disiss.

Kaolinito.

Laumontit

Illito.

gChlorito. 
Table III lists the phases for which we presently have calibration data along with the standards we use, their RIRs, and their source. We have found that RIRs remain relatively constant from sample to sample for the silica phases and either are constant or can be compensated for in most other phases such as feldspars and zeolites. Illite/smectites (I/S), however, show a wide variation in RIRs. There are several reasons postulated for this. The most significant cause must be preferred orientation, although other possible causes include interstratification, chemical composition, and relative humidity differences between the run times for both samples and standards. We compensated for the variable RIR of I/S in UE-25p\#1 by conducting clay separations at intervals down the drill hole and then measuring RIRs on each of the separates to determine the most appropriate RIR for the I/S at a certain interval (Fig. 2).

Our methods of quantitative analysis are identical to the methods outlined in Bish and Chipera (1986), except that a newer version of our quantitative analysis computer program QUANT was used. QUANT5.01 differs from QUANT4 in that numerous phases have been added requiring that input and output routines be more phase specific in response to the increasing number of phases that can be analyzed. QUANT5 also incorporates the error calculation routines from our previous program RANGE, eliminating the need to re-input data to obtain full quantitative results. As we obtained more and better standards, we incorporated them into the new version of QUANT. Although the present version of QUANT has been upgraded to include more phases and become more "user friendly, "the results obtained with it do not significantly differ from those of its predecessor, QUANT4.

\section{MINERAL DISTRIBUTION}

The mineral distribution in drill hole UE-25p\#1 (Table II, Fig. 3) is similar to that of other drill holes at Yucca Mountain (e.g., USW G-1, J-13, UE-25a\#1). Tridymite occurs only near the surface, coexisting with cristobalite at a shallow depth before disappearing below $176.8 \mathrm{~m}$ (580 ft). Cristobalite disappears with the first appearance of clinoptilolite at $381.0 \mathrm{~m}$ (1250 
$\mathrm{ft}$ ), at which point opal-CT and quartz are the dominant silica phases. I/S occur throughout the drill hole in variable amounts, generally increasing in abundance with depth. Analcime first appears at $676.7 \mathrm{~m}(2220 \mathrm{ft})$ and is distributed in discrete zones in amounts less than $20 \%$ to the bottom of the hole. Calcite becomes more common in the deeper portions of the drill hole after analcime appears. Mordenite, which is common in many of the drill holes at Yucca Mountain, was sparse in UE-25p\#1; only 4 of the 40 zeolite-bearing samples analyzed contained mordenite. of the several clay minerals present, interstratified $\mathrm{I} / \mathrm{S}$ are the most abundant. Kaolinite occurs locally at the shallower depths down to about $762.0 \mathrm{~m}(2500 \mathrm{ft})$. Chlorite occurs in minor amounts ( $1 \%$ and less) in an interval from approximately 1097.3 to $1188.7 \mathrm{~m}$ $(3600$ to $3900 \mathrm{ft})$.

Some aspects of the mineralogy of the rocks from UE-25p\#1 proved to be slightly different from the mineralogy reported for other drill holes at Yucca Mountain. For the first time at Yucca Mountain, the Ca-zeolite laumontite was positively identified in four samples at and below $941.8 \mathrm{~m}$ (3090 ft), although its presence was suspected at the bottom of USW G-1 (Bish and Chipera 1986). Fluorite was also found locally at the bottom of UE-25p\#1, although fluorite has also been reported at the bottom of USW G-2 (Caporuscio et al. 1882). Since this drill hole penetrated the tuff sequences into the Paleozoic dolomite basement, it is also the first drill hole to contain dolomite, first appearing at 1146.0-m (3760-ft) depth.

Analcime's first appearance at approximately $676.7 \mathrm{~m}(2220 \mathrm{ft})$ is probably due to the reaction of clinoptilolite, although clinoptilolite coexists with analcime throughout the tuff sequences to the contact with the Paleozoic basement. Clinoptilolite compositions become increasingly more calcic with depth in UE-25p\#1 (Broxton et al. 1986). Based upon thejr Ca-rich compositions ( $\mathrm{Ca}>70 \%$ of exchange positions) and their low $\mathrm{Si} / \mathrm{Al}$ ratios (2.8 to 3.6), Broxton et al. (1987) speculated that some of the clinoptilolite-group zeolites occurring at deep levels in drill holes on the eastern side of Yucca Mountain, including those of UE-25p\#1, pere heulandite. Previously, heulandite had been found only in a thin zone of alteration on top of the basal vitrophyre of the Topopah Spring Member at relatively shallow depths. 
RBPBRBNCE INTENSITY RATIOS (RIRS) FOR YIMBRALS ANALYZBD BY QUANT5.01

REFLECTION

YINBRAL

SOURCB

tkl or $2 \theta$ RANGB

IIR

Analcime

Wikieup, $A Z$

$211 \quad(15.8) \quad 1.27$

$400 \quad(26.0) \quad 1.80$

Calcite

Lab Keagent

104

$(29.4)$

2.96

116

0.58

Chlorite

Flagstaff Hil1, OA,

Ripidolite

$\begin{array}{lrl}001 & (6.1) & 1.53 \\ 002 & (12.4) & 3.14 \\ 004 & (25.1) & 1.74\end{array}$

Clinoptilolite 25525 Castle Creek, ID 27032 Castle Creek, ID 27073 Sheaville, OR 27083 Buckhorn, NM

UE4P-1660 Yucca Mt, NV
$\begin{array}{lll}020 \quad(9.8) & 0.87\end{array}$ (22.4-22.7) 1.06 $(30.0) \quad 0.49$

Cristobalite Synthetic Cristobalite

$\begin{array}{lll}101 & (21.9) & 4.91 \\ 200 & (36.1) & 0.84 \\ & & \\ 104 & (30.9) & 2.69 \\ 113 & (41.1) & 0.48\end{array}$

Feldspar

Albite

Albite

Sanidine

Amelia, VA

Amelia, VA

Eifel, Germany

Sanidine

Eifel, Germany

$111 \begin{array}{ccc}(13.4-14.0 & 0.24 \\ & (23.6) & 0.27 \\ & (13.4-14.0) & 0.13 \\ & (23.6) & 0.55\end{array}$

Fluorite

Lab Reagent

i11 (28.3) 3.24

$220 \quad(47.0) \quad 3.70$

Gypsum

Wyi-ing Selenite

$020 \quad(11.5) 4 \quad 4.25$

Hematite

Cleater Moor, England

$104 \quad(33.2) \quad 2.38$

$110 \quad(35.7) \quad 1.20$

Hornblende

Yucca Mouriczin, NV

$110 \quad(10.4) \quad 2.34$

Illite

Silver Hill, MT

$001 \quad(8.8)$

0.57

Ilmenite

Koidu, Sierra Leono

$104 \quad(32.8)$

1.91

024

$\begin{array}{ll}(49.0) & 0.62\end{array}$

Kaolinite

Average of Wards Kaolin,

001

(12.3)

1.37

Washington County, GA

and Mesa Alta, NU 


\section{TABLB III (Cont)}

\begin{tabular}{|c|c|c|c|c|}
\hline YINERAL & SOURCB & $\begin{array}{r}\text { RF } \\
\text { hkl }\end{array}$ & $\begin{array}{l}\text { LBCTION } \\
2 \theta \text { RANGB }\end{array}$ & RIR \\
\hline Laumontite & $\begin{array}{l}\text { Collected by D. Bish in } \\
\text { Oregon, } 1884\end{array}$ & $\begin{array}{l}110 \\
200 \\
130\end{array}$ & $\begin{array}{l}(9.3) \\
(12.9) \\
(21.3)\end{array}$ & $\begin{array}{l}1.15 \\
0.47 \\
0.59\end{array}$ \\
\hline Magnetite & $\begin{array}{l}\text { Espanola, Ontario, } \\
\text { Canada }\end{array}$ & $\begin{array}{l}220 \\
311\end{array}$ & $\begin{array}{c}(30.1) \\
(35.4)\end{array}$ & $\begin{array}{l}0.78 \\
2.54\end{array}$ \\
\hline Mica & $\begin{array}{l}\text { Avg of calculated and } \\
\text { Bancroft, Ontario }\end{array}$ & 001 & $(8.8)$ & 3.8 \\
\hline Mordenite & $\begin{array}{l}\text { Union Pass, AZ } \\
\text { Lovelock, NV } \\
\text { USW G1-2314, Yucca Mt, NV }\end{array}$ & $\begin{array}{l}200 \\
330 \\
202\end{array}$ & $\begin{array}{l}(8.8) \\
(18.6) \\
(25.7)\end{array}$ & $\begin{array}{l}0.44 \\
0.20 \\
0.36\end{array}$ \\
\hline Opal-CT & $\begin{array}{l}28501 \text { Kliwikerthal, Czech. } \\
92509 \text { Owyhee County, ID }\end{array}$ & & $(.0-22.1)$ & 1.80 \\
\hline Quartz & Hot Springs, AR & $\begin{array}{l}100 \\
101\end{array}$ & $\begin{array}{l}(20.8) \\
(26.6)\end{array}$ & $\begin{array}{l}0.86 \\
4.18\end{array}$ \\
\hline Smectite & UE-25p\#1, Yucca Mt, NV & $\begin{array}{l}001 \\
001\end{array}$ & & $\begin{array}{l}3.85 \\
1.73\end{array}$ \\
\hline Tridymite & Nevada Test Site, NV & & $\begin{array}{l}(20.5) \\
(21.6)\end{array}$ & $\begin{array}{l}1.18 \\
1.10\end{array}$ \\
\hline
\end{tabular}

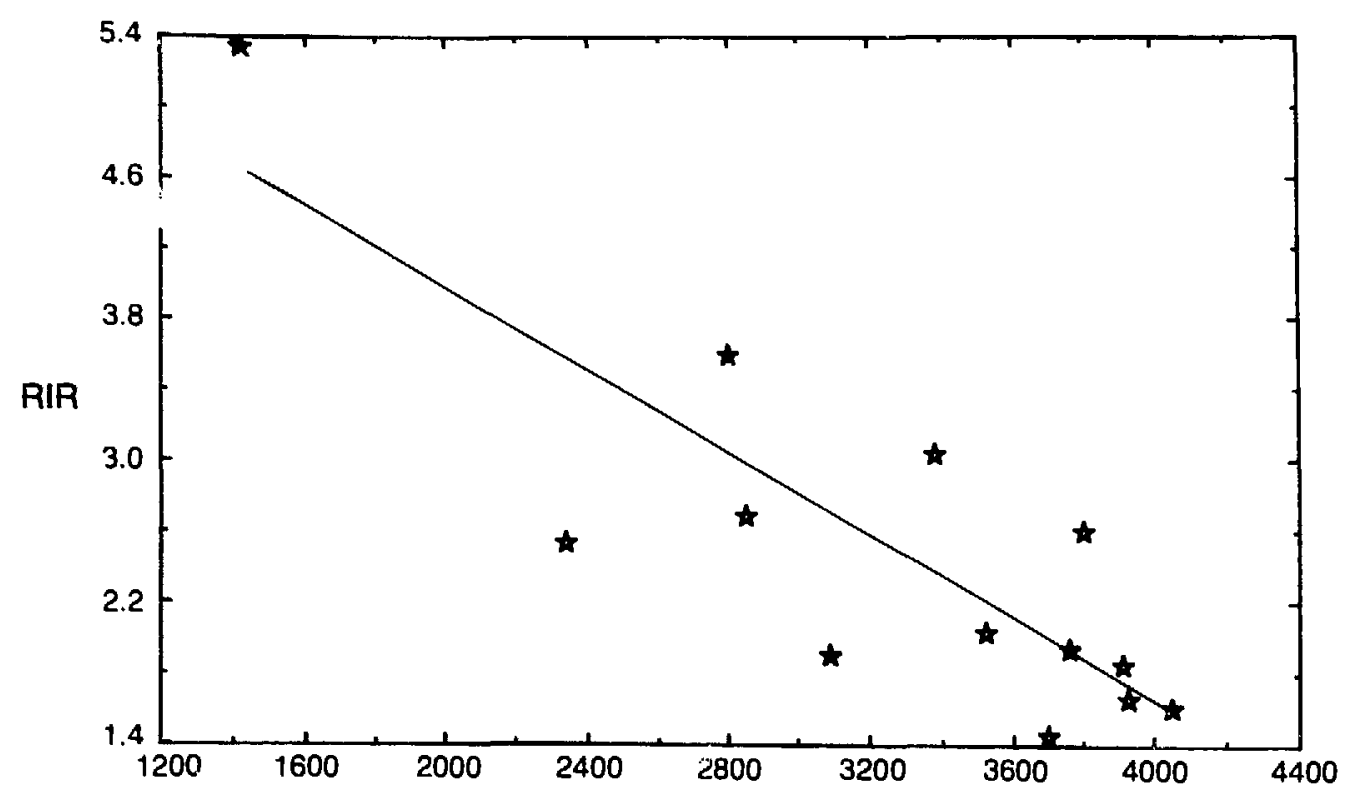

SAMPLE DEPTH (ft)

Fig. 2. Reference Intensity Ratio (RIR) vs depth for interstratified illite/smectite clays from drill hole UE-25p\#1. 


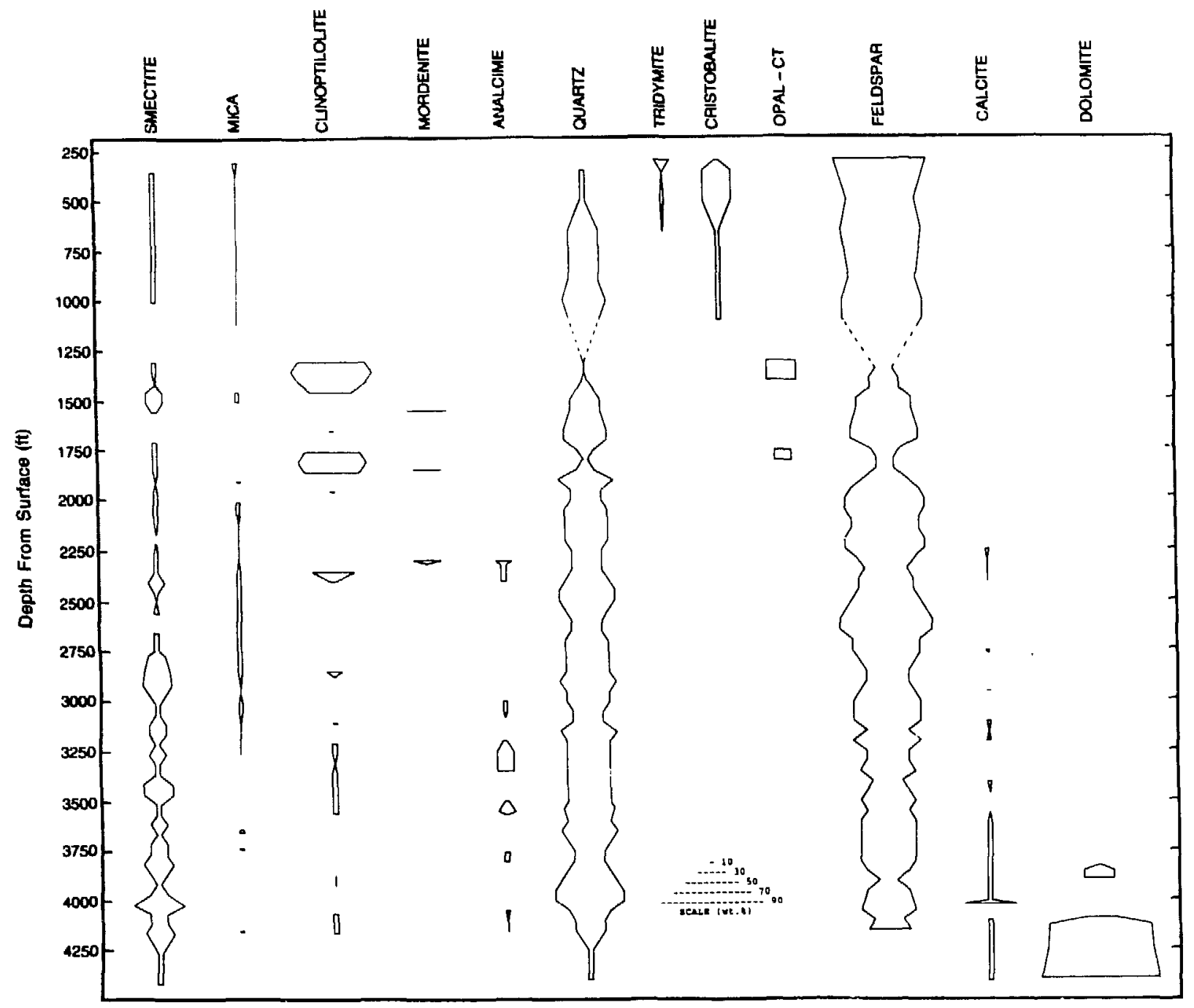

Fig. 3. Graphical representation of the data in Table I showing the relative abundance of minerals in drill hole UE-25p\#1. The scale can be used to estimate relative weight percentages. 
To determine the nature of the deeper clinoptilolite-group zeolites in UE-25p\#1, the zeolites in sample UE-25p\#1-3480/3490 were concentrated using a heavy-liquid density separation. A sodium polytungstate solution was prepared with a specific gravity of 2.35 . The $>10-\mu \mathrm{m}$ sample fraction was then suspended in the solution overnight, which allowed the heavier quartz $(\dot{c}=2.65)$ and feldspars ( $d=2.55-2.65$ ) to settle and the lighter zeolites $(d \simeq 2.2)$ to float. Clinoptilolite, originally composing $\sim 7 \mathrm{wt}$ of the rock, was concentrated to $\sim 45 \mathrm{wt}$, and analcime, originally at $\sim 4 \mathrm{wt}$, was concentrated to $\sim 40$ wt\%.

The concentrated material was suspended in deionized water, pipetted onto a silica-glass slide, and allowed to dry undisturbed. The mount was $x$-rayed, placed in a $450^{\circ} \mathrm{C}$ oven for $16 \mathrm{~h}$, and then re-x-rayed to determine the thermal stability of the zeolite. Mumpton (1960) has shown that clinoptilolite is stable up to $750^{\circ} \mathrm{C}$, whereas heulandite becomes amorphous when heated overnight at $450^{\circ} \mathrm{C}$.

The clinoptilolite-group zeolite diffraction pattern completely disappeared in the heated sample, confirming that the zeolite mineral is heulandite in UE-25p\#1-3480/3490. The other deeper clinoptilolite-group zeolites may also be heulandites, and we are beginning a survey of deep clinoptilolite-group zeolites at Yucca Mountain. The present-day ground water in UE-25p\#1 is enriched in $\mathrm{Ca}, \mathrm{Mg}$, and $\mathrm{Na}$ and has a low $\mathrm{Si}$ concentration compared with other ground waters at Yucca Mountain (Bish et al. 1884). The occurrence of heulandite instead of clinoptilolite in deeper portions of UE-25p\#1 may be related to the significantly different water composition in this drill hole. An interesting result of the heating of the zeolite-concentrated sample was that the analcime $x$-ray diffraction pattern changed significantly. The major reflection at $15.9^{\circ} 2 \theta$ increased and the reflections at $26.0^{\circ}$ and $30.5^{\circ} 2 \theta$ drastically decreased in intensity. The significance of this is unknown at this time and warrants further investigation.

It is interesting that the less thermally stable phase, heulandite, coexists with analcime in this drill hole whereas clinoptilolite exists at shallower depths and presumably reacts to form analcime. The reaction of clinoptilolite to analcime is believed to be dependent on the silica activity controlled by the existing silica phases (Kerrisk 1983; Duffy 1984; Bish 1987). This dependence generally results in the simultaneous disappearance of opal-CT and clinoptilolite with the formation of analcime. Since heulandite has a 
framework with a higher Al:Si ratio, it may be more stable than clinoptilolite with respect to the chemical potential of silica.

\section{CLAY MINERAL ANALYSES}

For the clay mineral separations, 20 to $40 \mathrm{~g}$ of powdered sample was suspended in 500 to $700 \mathrm{ml}$ of deionized water in a plastic 1000-ml beaker. To disaggregate the sample, the beaker containing the suspended sample was vibrated ultrasonically for 10 min using a Braun-Sonic 1510 ultrasonic probe operating at $200 \mathrm{~W}$ with a 19 -mm-diameter probe. After disaggregation, the beaker was covered and placed on a vibrationally stable surface overnight (16 to $20 \mathrm{~h}$ ) to allow the greater than $\simeq 1-\mu$ m material to settle out. The material remaining in suspension was decanted into centrifuge tubes and centrifuged at $5000 \mathrm{rpm}$ for $5 \mathrm{~min}$ to remove the $>0.35-\mu \mathrm{m}$ material. We have found that this treatment removes most of the quartz, leldspars, zeolites, and other nonclay minerals from suspension. After centrifugation, the supernatant was decanted into other centrifuge tubes and centrifuged at a speed of $8000 \mathrm{rpm}$ for $40 \mathrm{~min}$ to remove the $>0.10-\mu \mathrm{m}$ material. The final supernatant was heated on a $50^{\circ} \mathrm{C}$ hotplate to evaporate most of the water and concentrate the $<0.10-\mu m$ material.

$X$-ray powder diffraction of clay minerals usually involves the preparation of oriented mounts. A variety of procedures exist for producing oriented mounts (see Brindley and Brown 1980, p. 309), so we will briefly outline the method that we used. The fine $\mathrm{I} / \mathrm{S}(<0.35 \mu \mathrm{m})$ were suspended in deionized water and ultrasonically vibrated if necessary. This suspension was then pipetted onto an off-axis-cut quartz slide and allowed to dry undisturbed on a clean, level, vibrationally stable surface. Only enough sample to cover the slide was used, and the slide was not overfilled nor was more suspension added after drying began. This produced an oriented mount on which the majority of the individual clay crystallites (platelets in form) were parallel to the quartz plate resulting in an 001 series of basal reflections with little or no evidence of hkl reflections. The basal spacing determined from patterns of oriented mounts is related to the type of layers present, and thus this technique is very useful for clay mineral identification. These mounts are the type most commonly used in the study of interstratified clay minerals. The techniques employed to investigate these more complex clays are beyond the scope of this report and are given in Bish (1887). 
The oriented mounts of $\mathrm{I} / \mathrm{S}$ were $\mathrm{x}$-rayed both at room temperature and humidity and after solvation in an ethylene-glycol atmosphere overnight. To interpret the patterns of ethylene-glycol-solvated interstratified I/S, we used the method of Reynolds (1980). (See also Reynolds and Hower 1970; Srodon 1980; Hower 1981.) Observed diffraction patterns were compared with patterns calculated using a FORTRAN version of Reynold's (1980) computer program. Table IV lists the type of interstratification and the percentage of collapsed layers for the separated I/S.

It is interesting to note that in most $\mathrm{I} / \mathrm{S}$ from this drill hole, there are two distinct interstratified I/S (Fig. 4). One is an ordered interstratification (up to $R=1$, allevardite) and possesses a higher percentage of collapsed layers (up to $75 \%$ ). The other is randomly interstratified with approximately $15 \%$ to $20 \%$ collapsed layers. Both I/S are dioctahedral.

It is apparent from the data in Table $I V$ that the $I / S$ are randomly interstratified with a low percentage of collapsed layers at shallow depths (UE25p\#1-1420SW = 15\%). The percentage of collapsed layers, however, increases systematically with depth. The interstratification is random until between 868.7 and $941.8 \mathrm{~m}$ (2850 to $3090 \mathrm{ft}$ ) whereupon slight ordering develops. At this depth, we also begin to see evidence for discrete illite in the rocks. Ordering rapidly reaches $R=1$ (allevardite) between 1030.2 and 1072.8 m (3380 to $3520 \mathrm{ft}$ ) in depth. As no $\mathrm{I} / \mathrm{S}$ were found with $\mathrm{R} \geq 3$ (Kalkberg) ordering, the clay mineralogy suggests a maximum alteration temperature of $175^{\circ} \mathrm{C}$ (Hower and Altaner 1983). These changes in clay mineralogy are accompanied by significant changes in the chemistry of the clinoptilolite-heulandite group zeolites. The $\mathrm{Si} / \mathrm{Al}$ ratios change from 4 to 5 above $841.2-\mathrm{m}(2760-\mathrm{ft})$ depth to $\sim 3.5$ at $1015.0-m(3330-f t)$ depth. The higher $\mathrm{Si} / \mathrm{Al}$ ratios are usually associated with clinoptilolite, whereas ratios of $\sim 3.5$ are typical of heulandite.

The two distinct types of $\mathrm{I} / \mathrm{S}$ are evidence that a minimum of two alteration events has occurred in UE-25p\#1. The first alteration event was a higher temperature event resulting in $I / S$ of $R=1$ (allevardite) ordering. The second alteration event was less intense, resulting in randomly interstratified I/S with less than $20 \%$ collapsed layers. This second event was not intense enough to reset or retrograde the previously formed interstratified I/S.

The heat and fluids for these events could have been derived from a number of sources. Without separating the two clays and dating each one, it is 
TABLB IV

I/S INTERSTRATIPICATIONS

Drill Hole UB-25p 1

PBRCBNT COIPLEX COLLAPSED THICKNESS

SAYPLB LAYYBRS (A) INTBRSTRATIPICATIOK Contrits

$\begin{array}{rcccc}1420 S W & 15 & 16.7 & \text { Random } & \\ 2340 & 25 & 16.8 & \text { Random } & \text { Two clays, cannot decompose } \\ 2800 \# 1 & 25 & 16.8 & \text { Random } & \\ \text { \#2 } & 40 & 16.8 & \text { Random } & \\ 2850 & 35 & 16.8 & \text { Random } & \text { Two clays, cannot decompose } \\ 3090 & 40 & 16.8 & \text { Random } & \text { Two clays, can't decompose } \\ 3380 & 40 & 16.8 & \text { Random } & \text { Two clays ??? } \\ 3520 \text { \#1 } & 20 & 16.7 & \text { Random } & \\ \# 2 & 55 & ? ? & \text { Allevardite } & \text { Poor Resolution } \\ 3700 \text { \#1 } & 15 & 16.7 & \text { Random } & \\ \# 2 & 60 & 16.6 & \text { Allevardite } & \text { Poor Resolution } \\ 3760 \# 1 & 15 & 16.7 & \text { Random } & \\ \# 2 & ? ? & ? ? & \text { Allevardite } & \text { Poor Resolution } \\ 3800 \# 1 & 20 \pm 10 & ? ? & \text { Random } & \text { Poor Resolution } \\ \# 2 & 75 & 16.6 & \text { Allevardite } & \\ 3913 C \# 1 & ? ? & ? ? & \text { Random } & \text { Poor Resolution } \\ \# 2 & 75 & 16.6 & \text { Allevardite } & \\ 3928 C \# 1 & 20 \pm 10 & ? ? & \text { Random } & \text { Poor Resolution } \\ \# 2 & 65 & 16.7 & \text { Allevardite } & \\ 4050 \# 1 & 15 & 16.7 & \text { Random } & \\ \# 2 & 70 & 16.7 & \text { Allevardite } & \\ 4080 \# 1 & 15 & 16.7 & \text { Random } & \\ \# 2 & 70 & 16.6 & \text { Allevardite } & \text { Poor Resolution } \\ 4180 \# 1 & 15 & 16.7 & \text { Random } & \\ \# 2 & 75 & 16.8 & \text { Allevardite } & \\ & & & & \end{array}$


difficult to speculate as to the alteration timing and fluid sources. Yucca Mountain is in an area that has been volcanically active in the past, and it is bordered by numerous ancient caldera complexes (Byers et al. 1976) that could have produced the observed alteration. Illites from drill holes USW G-1 and G2 have been dated using K/Ar techniques (Bish 1987; Aronson and Bish 1987), yielding ages of about $11 \mathrm{Myr}$, which are consistent with Timber Mountain volcanism to the north, a source of hydrothermal alteration. Bish (1987) showed that, in addition to the primary alteration event, evidence exists for continued low-temperature formation of minerals in USW G-1 and G-2. This is demonstrated by I/S with a low percentage of collapsed (illice) layers occurring deeper than higher-temperature-ordered I/S in both USW G-1 and G-2. In addition, he examined one sample that contained both discrete illite and randomly interstratified I/S with only about $20 \%$ collapsed layers. Considering the similarity of the clays in UE-25p\#1 to those in USW G-1 and G-2 and the proximity of UE-25p\#1 to these two drill holes, the primary alteration event in UE-25p\#1 is likely related to the alteration event apparent in USW G-1 and G-2. It is, however, more difficult to correlate the second, lower temperature alteration event with that seen in USW G-1 or G-2.

The transformations in clay mineralogy with depth can yield information concerning the temperatures to which the rocks have been subjected by employing the data of Hower and Altaner (1983). Figure 5 is a summary diagram of the relationship between temperature and the extent of the smectite-to-illite reaction, incorporating data from pelitic rocks as well as active geotherwal areas (Steiner 1968; Eslinger and Savin 1873; Hoffman and Hower 1979; McDowell and Elders 1980). Hower and Altaner (1983) and Thompson and Jennings (1985) concluded that the reactions below $150^{\circ} \mathrm{C}$ involving randomly interstratified $\mathrm{I} / \mathrm{S}$ and $R=1 \mathrm{I} / \mathrm{S}$ are kinetically controlled. In a prograde sequence, $\mathrm{R}=1 \mathrm{I} / \mathrm{S}$ are formed at $90^{\circ}$ to $100^{\circ} \mathrm{C}$ over long reaction times $\left(>10^{7} \mathrm{yr}\right.$ ) but over short reaction times $\left(<10^{\circ} \mathrm{yr}\right)$ at $130^{\circ}$ to $150^{\circ} \mathrm{C}$. Apparently these clay mineral reactions are not kinetically limited at temperatures over $130^{\circ}$ to $150^{\circ} \mathrm{C}$.

It is impossible to compare directly the environmental conditions such as alteration temperature between UE-25p\#1 and other drill holes based on interstratifications of $\mathrm{I} / \mathrm{S}$ alone. The smectite-to-illite reaction is influenced by several variables, including time, temperature, mineralogic assemblage, and water composition (Eberl and Hower 1976; Howard 1981; McCubbin and Patton 1881; 


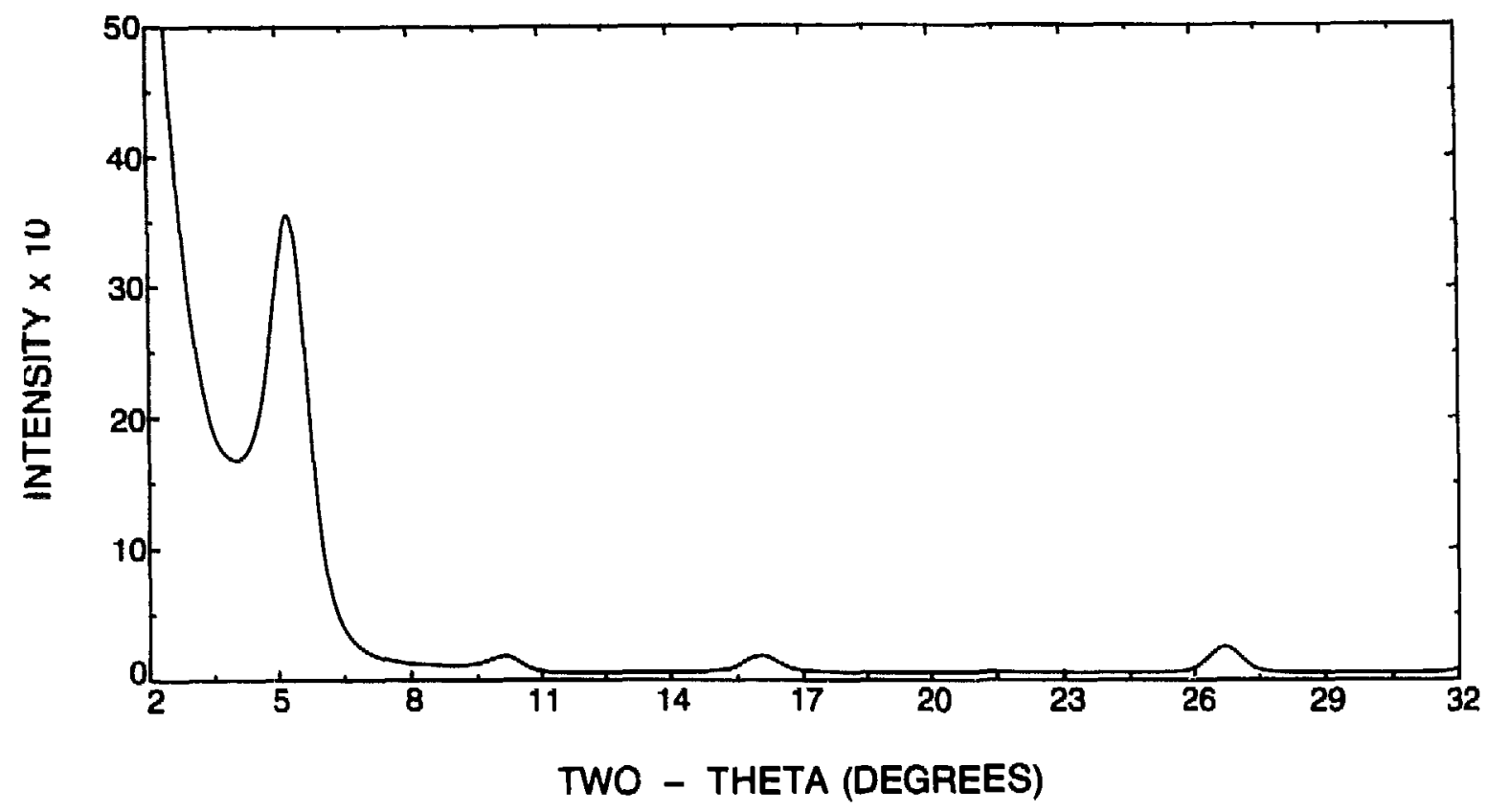

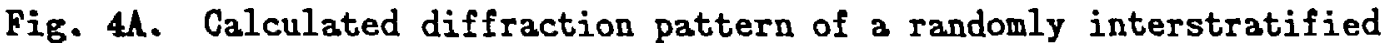
illite/smectite, with $20 \%$ collapsed layers and an ethylene-glycol complex thickness of $16.7 \AA$.

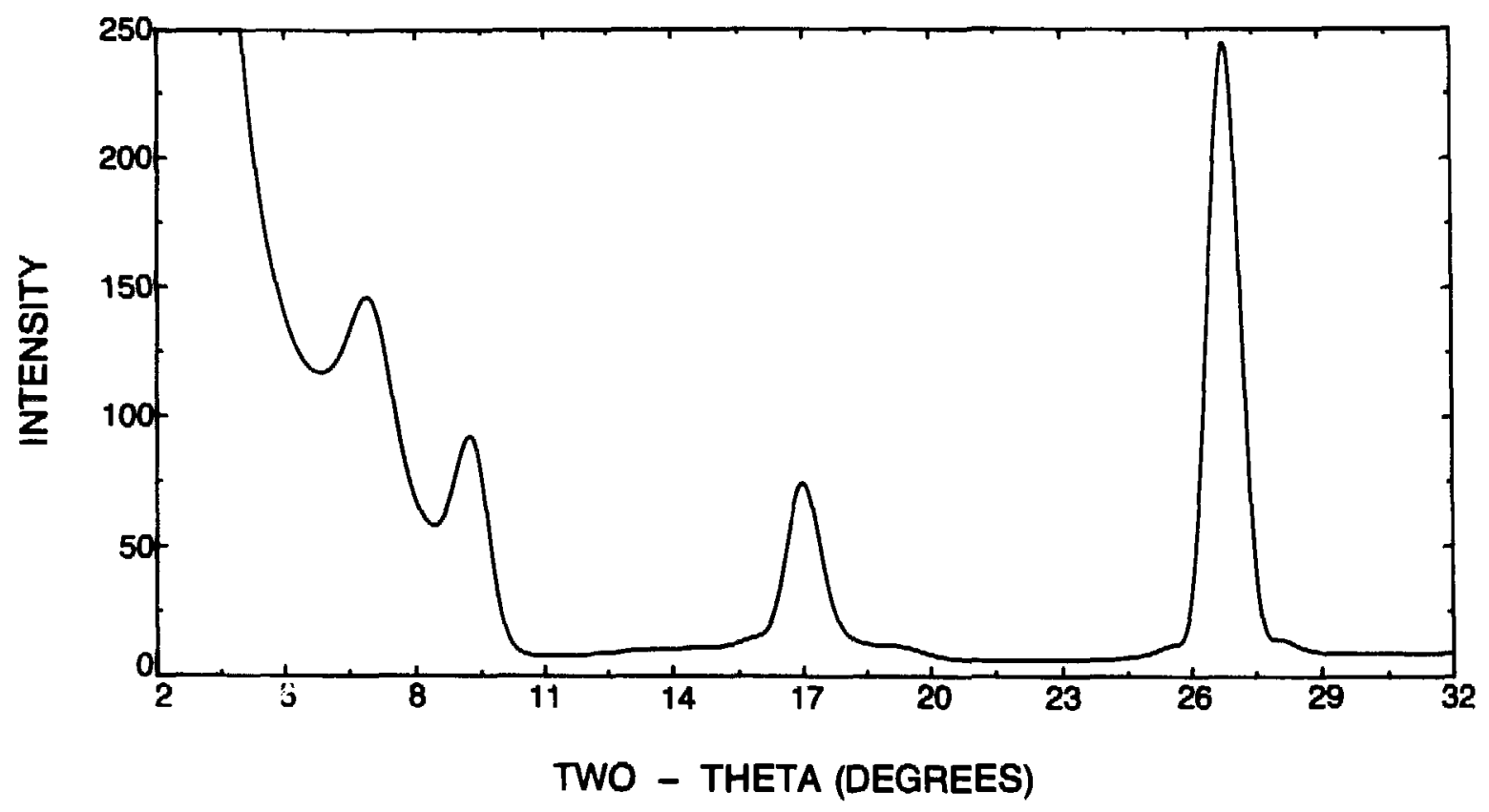

Fig. 4B. Calculated diffraction pattern of an $\mathrm{R}=1$ (allevardite) illite/smectite, with 75\% collapsed layers and an ethylene-glycol complex thickness of $16.6 \%$. 


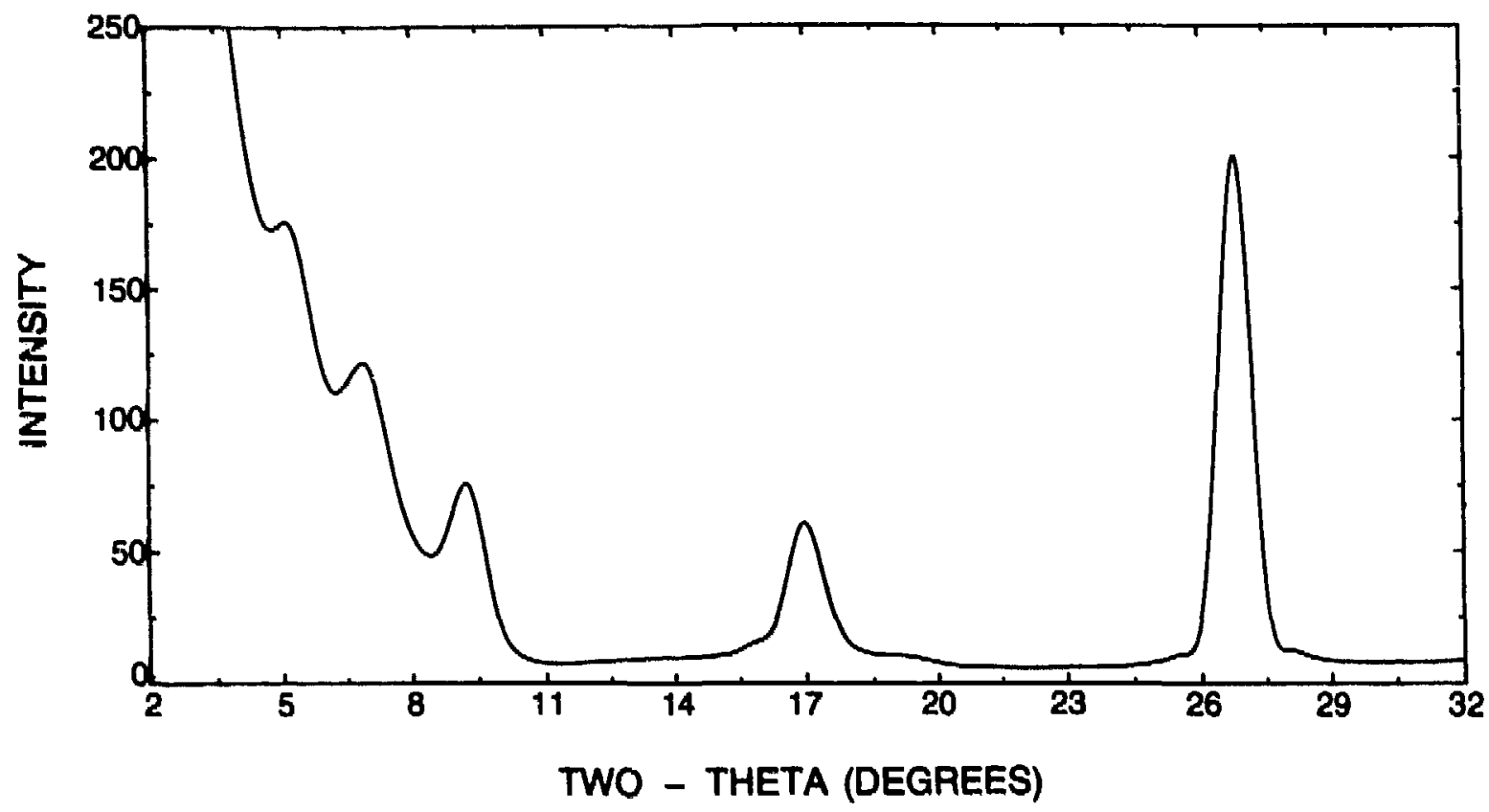

Fig. 4C. Calculated diffraction pattern using the sum of the patterns from Fizs. $4 \mathrm{~A}$ and $4 \mathrm{~B}$ at a ratio of $20: 80$. Excluding the low-angle background for this pattern, this is a very close fit to sample UE-25p\#1-3790/3800 (Fig. 4D), which is composed of two distinct illite/smectites.

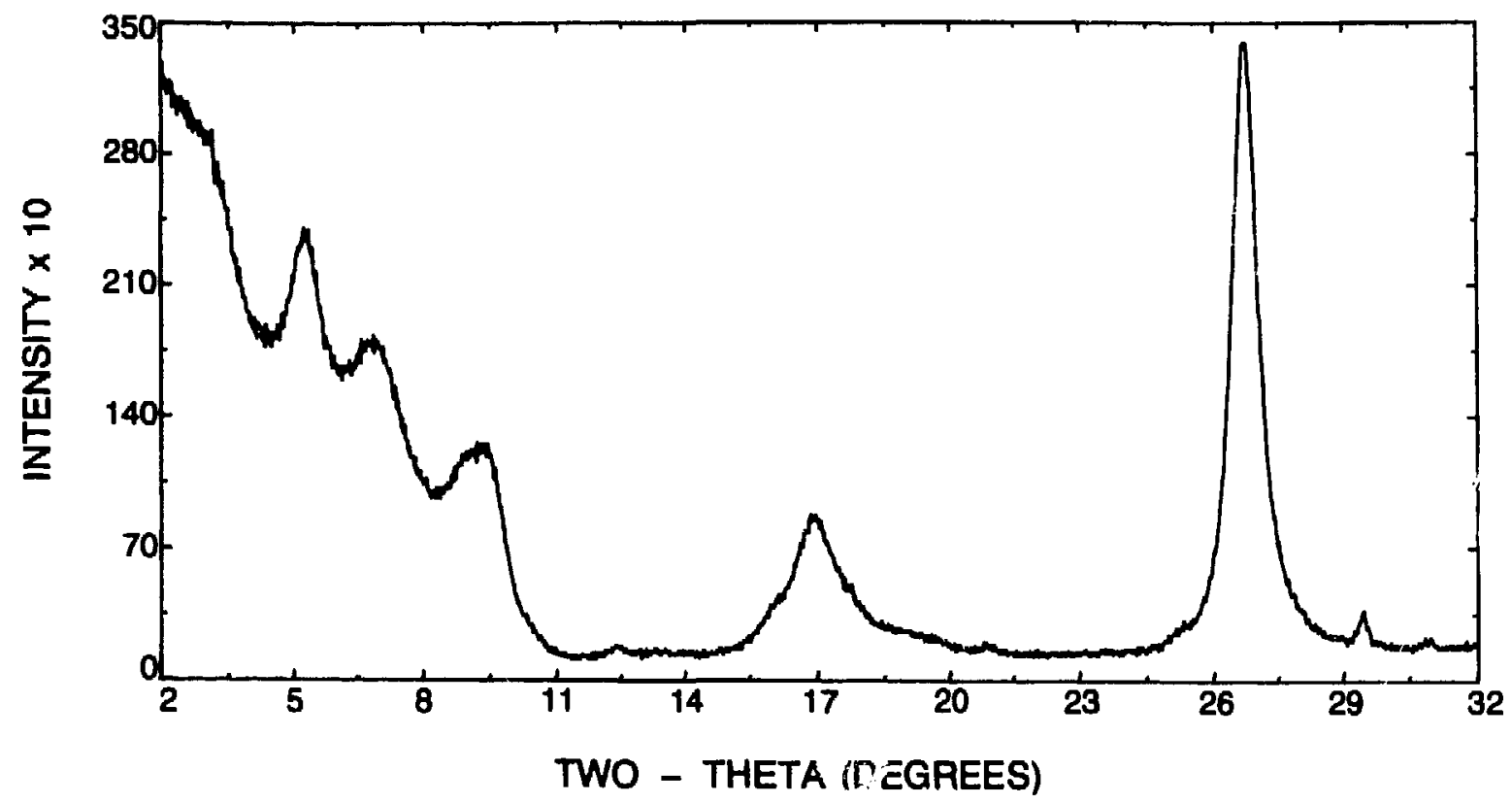

Fig. 4D. Observed diffraction pattern of sample UE-25p\#1-3790/3800. 


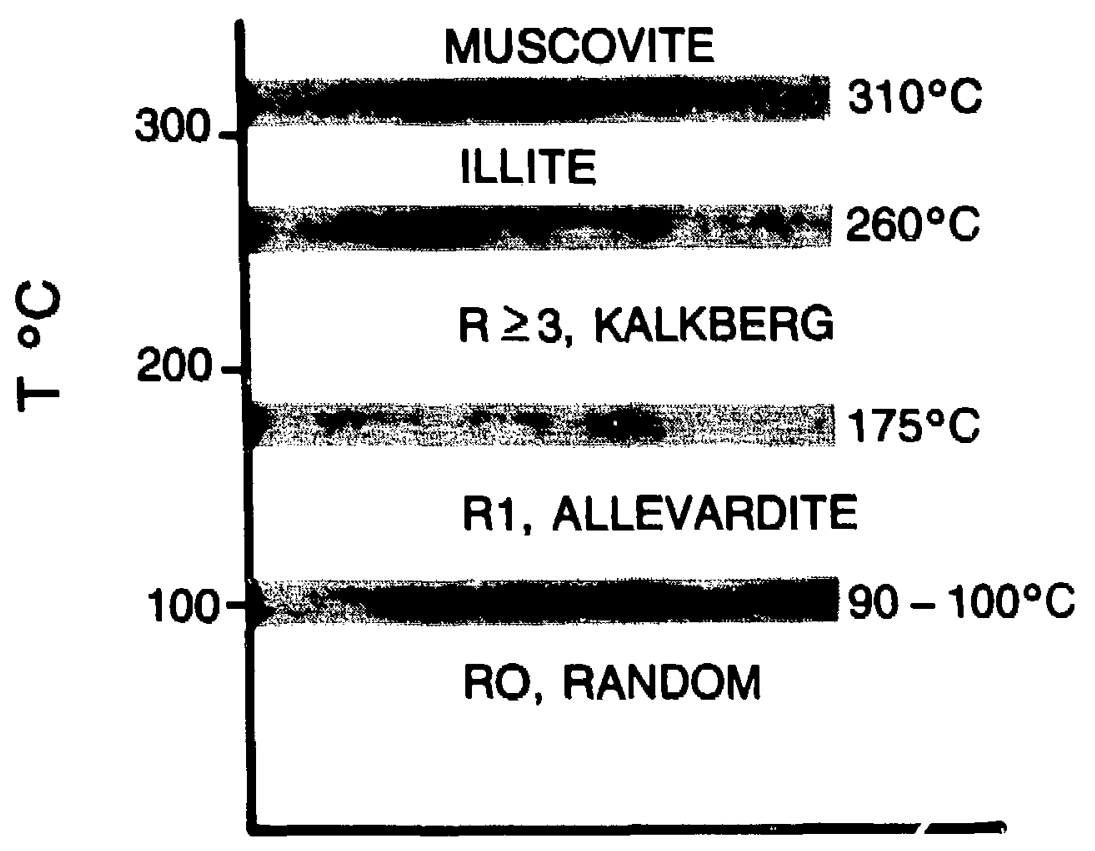

Fig. 5. Relationship between temperature and extent of smectite-to-illite reaction (from Hower and Altaner 1983).

Roberson and Lahann 1981). The chemical composition of the saturating fluids plays an important role in determining the nature of the smectite-to-illite reaction. High $K$ content in the fluids tends to promote the smectite-to-illite reaction (Whitney and Northrop 1987), whereas low $K$ concentrations and the presence of other ions such as $\mathrm{Ca}, \mathrm{Mg}$, and $\mathrm{Na}$ inhibit the reaction (Howard 1981; Roberson and Lahann 1981). The present-day ground water from UE-25p\#1 is significantly enriched in $\mathrm{Ca}, \mathrm{Mg}$, and $\mathrm{Na}$ compared with waters from other drill holes at Yucca Mountain (Bish et al. 1984). If fluids present during alteration were similarly enriched in these ions, the smectite-to-illite reaction in UE-25p\#1 may have been inhibited compared with the reaction in USW G-1 and G-2.

Broxton et al. (1987) showed that the exchangeable cations in the clinoptilolite-group minerals are calcic in the eastern region of Yucca Yountain, whereas they are more sodic in the western region of Yucca Mountain. They attributed this to the infiltration of $\mathrm{Ca}$ - and $\mathrm{Mg}$-rich ground water from the Paleozoic carbonate basement, which is shallower in the eastern region of Yucca Mountain, into the tuffaceous volcanic rocks. Craig and Robison (1984) conducted a study of the geohydrologic properties of drill hole UE-25p\#1. Among their findings was that the hydraulic head was $20 \mathrm{~m}$ greater in the 
Paleozoic section of the drill hole than in the Tertiary section. They concluded that there is a confining layer that retards the vertical movement of ground water. The confining layer with the minimum vertical hydraulic conductivity occurred between 1114 and $1180 \mathrm{~m}$ ( 3655 to $3871 \mathrm{ft}$ ), toward the bottom of the Tertiary sequence. Units in this interval included $23 \mathrm{~m}$ of the unnamed older tuff (unit C), $34 \mathrm{~m}$ of an unnamed conglomerate, and $9 \mathrm{~m}$ of a calcified ash-flow tuff (Table I). They considered the clay-stone matrix conglomerate layer to be the probable confining layer. Our mineralogical data show that an interval in the calcified ash-flow tuff ( 3813 to $3828 \mathrm{ft}$ ) contains 37 to $45 \mathrm{wt} \%$ $\mathrm{I} / \mathrm{S}$ and could easily give rise to a low permeability layer. The extent of this illite/smectite-rich layer is unknown due to limited sampling in this depth interval. The hydraulic data also demonstrate that any intercommunication between the Tertiary and Paleozoic aquifers, although retarded by the confining layer, would result in the upward movement of ground water from the Paleozoic carbonates into the Tertiary volcanic section.

\section{SUMMARY}

Drill hole UE-25p\#1, although not in the repository block itself, is important in that it provides information on the geology of the nearby accessible environment. It is also unique in that it is the only drill hole to go completely through the Tertiary volcanic rocks and penetrate the underlying basement of Paleozoic dolomite.

The mineralogy in UE-25p\#1 is similar to that in the other drill holes at Yucca Hountain, and the same variations in silica minerals, zeolites, and clay minerals occur with depth. Differences in ineralogy include the occurrence of dolomite in the deep carbonate rocks and the coexistence of analcime and heulandite. For the first time, the Ca-zeolite laumontite has been positively identified, although its presence was suspected in USW G-1.

Most of the illite/smectite-bearing samples in UE-25p\#1 contain two distinct pairs of interstratified I/S. One is ordered interstratified illite/smectite (up to $\mathrm{R}=1$, allevardite, $75 \%$ collapsed), and the other is randomly interstratified smectite-rich illite/smectite (approximately $15 \%$ to $20 \%$ collapsed). The two distinct $\mathrm{I} / \mathrm{S}$ are clear evidence that a minimum of two alteration events has occurred in UE-25p\#1. The first event was a higher temperature event resulting in clays of $R=1$ ordering. Since no clays of $R \geq 3$ ordering were found, the clay mineralogy suggests a maximum temperature of less 
than $175^{\circ} \mathrm{C}$ for this event. Noting the similarity of these clays to those in USW G-1 and G-2, which were dated at approximately $11 \mathrm{Myr}$ using K/Ar methods, Timber Mountain volcanism is the likely source for this alteration, which appears to have significantly affected all of the deeper rocks in the northern half of Yucca Mountain. The second alteration event was not as intense, nor did it reset or retrograde the previous event. At present, we are unable to speculate as to the date of this alteration event.

\section{ACKNOWLEDGMENTS}

We are grateful to D. Broxton for assistance with the heavy-liquid separation technique and for useful comments on the manuscript.

\section{REFERENCES}

Aronson, J. L., and D. L. Bish, "Distribution, K/Ar Dates, and Origin of Illite/Smectite in Tuffs from Cores USW G-1 and G-2, Yucca Mountain, Nevada, a Potential High-Level Radioactive Waste Repository, "Proceedings of the Clay Minerals Society 24th Annual Meeting, Socorro, New Mexico (October 1987), p. 25.

Bish, D. L., "Evaluation of Past and Future AIterations in Tuff at Yucca Mountain, Nevada, Based on the Clay Mineralogy of Drill Cores USW G-1, G-2, and G-3," Los Alamos National Laboratory report LA-10667-MS (Submitted 1886).

Bish, D. L., and S. J. Chipera, "Mineralogy of Drill Holes J-13, UE-25A\#1, and USW G-1 at Yucca Mountain, Nevada," Los Alamos National Laboratory report LA-10764-MS (September 1986).

Bish, D. L., A. E. Ogard, D. T. Vaniman, and L. Benson, "Mineralogy-Petrology and Groundwater Geochemistry of Yucca Mountain Tuffs, "Materials Research Society Symposium Proceedings 26, 283-291 (1984).

Brindley, G. W., and G. Brown, Crystal Structures of Clay Minerals and Their X-Ray Identification (Mineralogical Society, London, 1980).

Broxton, D. E., D. L. Bish, and R. G. Warren, "Distribution and Chemistry of Diagenetic Minerals at Yucca Mountain, Nye County, Nevada," Clays and Clay Minerals $\underline{35}, 89-110$ (1987).

Broxton, D. E., R. G. Warren, R. C. Hagan, and G. Luedemann, "Chemistry of Diagenetically Altered Tuffs at a Potential Nuclear Waste Repository, Yucca Mountain, Nye County, Nevada," Los Alamos National Laboratory report LA-10802-MS (October 1986). 
Byers, F. M., Jr., W. J. Carr, P. P. Orkild, W. D. Quinlivan, and K. A. Sargent, "Volcanic Suites and Related Cauldrons of Timber Mountain-0asis Valley Caldera Complex, Southern Yevada, "U. S. Geological Suryey Professional Paper 919 (1976).

Byers, F. M., Los Alamos National Laboratory, personal communication (November 1985).

Caporuscio, F., D. Vaniman, D. Bish, D. Broxton, B. Arney, G. Heiken, F. Byers, R. Gooley, and E. Semarge, "Petrologic Studies of Drill Cores USW-G2 and UE25b-1H, Yucca Mountain, Nevada," Los Alamos National Laboratory report LA-9255-MS (July 1982).

Carr, M. D., S. J. Waddell, G. S. Vick, J. M. Stock, S. A. Monsen, A. G. Harris, B. W. Cork, and F. M. Byers, Jr., "Geology of Drill Hole UE25P\#1: A Test Hole into Pre-Tertiary Rocks Near Yucca Mountain, Southern Nevada, " U. S. Geological Survey Open-File Report 86-175, 87 pp. (1986).

Chung, F. H., "Quantitative Interpretation of X-Ray Diffraction Patterns of Mixtures. I. Matrix-Flushing Method for Quantitative Multicomponent Analysis," Journal of Applied Crystallography 7, 519-525 (1974a).

Chung, F. H., "Quantitative Interpretation of X-Ray Diffraction Patterns of Mixtures. II. Adiabatic Principle of X-Ray Diffraction Analysis of Mixtures," Journal of Applied Crystallography $\underline{7}, 526-531$ (1974b).

Craig, R. W., and J. H. Robison, "Geohydrology of Rocks Penetrated by Test Well UE-25P\#1, Yucca Mountain Area, Nye County, Nevada, "U. S. Geological Survey Water-Resources Investigations Report 84-4248, 57 pp. (1984).

Duffy, C. J., "Hydrotherinal Geochemistry," in "Research and Development Related to the Nevada Nuclear Waste Storage Investigations, October 1 December 31, 1983," K. Wolfsberg and D. T. Vaniman, Comp., Los Alamos National Laboratory report LA-10032-PR (August 1984).

Eberl, D., and J. Hower, "Kinetics of Illite Formation," Geological Society of America Bulletin 87, 1326-1330 (1976).

Eslinger, E. V., and S. M. Savin, "Mineralogy and Oxygen Isotope Geochemistry of the Hydrothermally Altered Rocks of the Ohaki-Broadlands, New Zealand Geothermal Area," American Journal of Science 273, 240-267 (1973).

Hoffman, J., and J. Hower, "Clay Mineral Assemblages as Low Grade Metamorphic Geothermometers: Application to the Thrust Faulted Disturbed Belt of Montana, U.S.A.," Society of Economic Paleontologists and Mineralogists, Special Publication 26, 55-79 (1979).

Howard, J. J., "Lithium and Potassium Saturation of Illite/Smectite clays From Interlaminated Shales and Sandstones," Clays and Clay Minerals 29, 136-142 (1981). 
Hower, J., "X-Ray Diffraction Identification of Mixed-Layer Clay Minerals," in Clays and The Resource Geologist, Chap. 3, F. J. Longstaffe, Ed. (Mineralogical Association of Canada, Calgary, 1981), pp. 39-59.

Hower, J., and S. P. Altaner, "The Petrologic Significance of Illite/ Smectite," Proceedings of the Clay Minerals Society 20th Annual Meeting, Buffalo, New York (October 1983), p. 40.

Kerrisk, J. F., "Reaction-Path Calculations of Groundwater Chemistry and Mineral Formation at Rainier Mesa, Nevada," Los Alamos National Labor-tory report LA-9912-MS (December 1983).

McCubbin, D. G., and J. W. Patton, "Burial Diagenesis of Illite/Smectite: The Kinetic Model," Annual Meeting American Association of Petroleun Geologists, San Francisco, California, 1981 (Abstract).

McDowell, S. D., and W. A. Elders, "Authigenic Layer Silicate Minerals in Borehole Elmore 1, Salton Sea Geothermal Field, California, USA," Contributions to Mineralogy and Petrology 74, 283-310 (1880).

Mumpton, F. A., "Clinoftilolite Redefined," American Mineralogist 45, 351-369 (1960).

Reynolds, R. C., "Interstratified Clay Minerals," in Crystal Structures of Clay Minerals and Their X-Ray Identification, Chap. 4, G. W. Brindley and G. Brown, Eds. (Mineralogical Sociaty, London, 1980), pp. 249-304.

Reynolds, R. C., and J. Hower, "The Nature of Interlayering in Mixed-Layer Illite/Montmorillonite," Clays and Clay Minerals 18, 25-36 (1970).

Roberson, II. E., and R. W. Lahann, "Smectife to Illite Conversion Rates: Effects of Solution Chemistry, " Clays and Clay Minerals 29, 129-135 (1981).

Srodon, J., "Prccise Identification of Illite/Smectite Interstratifications by X-Ray Posder Diffraction," Clays and Clay Minerals $\underline{28,401-411}$ (1980).

Steiner, A., "Clay Minerals in Hydrothermally Altered Rocks at Wairakei, New Zealand," Clays and Clay Minerals 16, 193-213 (1968).

Thompson, G., and S. Jennings, "Kinetic Factcrs Affecting the Diagenetic Transformation of Smectite to Illite," Proceedings of the International Clay Conference, Denver, Colorado (1985), p. 239.

Whitney, G., and H. R. Northrop, "Experimental Investigation of Factors Affecting Rates of Illitization: Rock/Water Ratio, Potassium Availability, Ionic Strength, and Na/K Ratio," Proceedings of the Clay Minerals Society 24th Annual Meeting, Socorro, New Mexico (1987), p. 145. 